\title{
PEMBUATAN BAHAN BAKAR ALTERNATIF DARI MINYAK BIJI JARAK MENGGUNAKAN GELOMBANG MIKRO
}

\author{
Fitria $^{1}$, Ahmad Yani ${ }^{2}$ \\ Jurusan Teknik Kimia Sekolah Tinggi Teknologi Industri Bontang \\ JI. Brigjen Katamso No. 40 Bontang - Kalimantan Timur \\ Email: tekimfitri@gmail.com'; yanibima@gmail.com²
}

\begin{abstract}
Abstrak
Biodiesel merupakan salah satu bahan bakar alternatif. Beberapa penelitian yang telah dilakukan dalam pemenfaatan energi alternatif terbaharukan ini, diantaranya adalah biodiesel dari minyak nabati. Minyak nabati yang dapat digunakan dalam pembuatan biodiesel contohnya, minyak sawit, minyak jarak pagar, minyak biji karet, minyak kelapa, minyak kedelai, minyak jagung, minyak biji bunga matahari, dan bahkan minyak goreng bekas. Dalam penelitian ini mempelajari pembuatan biodiesel dari minyak biji jarak pagar (Jatropha Curcas $L$ ). Jarak pagar (Jatropha Curcas $L$ ) adalah tanaman cepat tumbuh dan sangat toleran terhadap iklim tropis dan jenis tanah, sehingga sesuai untuk dikembangkan sebagai tanaman konservasi. Selain itu, minyak dari bijinya dapat digunakan sebagai bahan energi. Bahkan bagian lain dari tanaman ini dapat dimanfaatkan untuk berbagai tujuan khusus. Tujuan penelitian ini adalah mengetahui pengaruh daya gelombang mikro terhadap konversi minyak biji jarak menjadi metil ester, pengaruh konsentrasi katalis terhadap Yield yang dihasilkan dan mengetahui pengaruh waktu reaksi pada proses transesterifikasi minyak biji jarak dengan menggunakan radiasi gelombang mikro. Pemanfaatan gelombang mikro pada reaksi transesterifikasi minyak jarak dapat dilakukan dengan konsentrasi yang lebih rendah serta waktu reaksi yang lebih cepat jika dibandingkan dengan metode konvensional. Dari penelitian ini juga dapat disimpulkan untuk nilai viskositas, semakin lama waktu yang digunakan untuk pemancaran gelombang mikro maka nilai viskositasnya mengalami penurunan. Pemanfaatan gelombang mikro pada reaksi transesterifikasi minyak jarak dapat dilakukan dengan konsentrasi yang lebih rendah serta waktu reaksi yang lebih cepat jika dibandingkan dengan metode konvensional. Yield biodiesel yang dihasilkan pada masing variasi daya 100, 180, dan 300 Watt, waktu reaksi 15 menit dengan konsentrasi katalis 0,75 \% Yield sebesar 56,12 \%, 56,84 \%, dan 56,86\%. Sedangkan pada daya 450 watt diperoleh Yield 69,09\% dengan waktu reaksi 10 menit, dan konsetrasi katalis 0,75\% dengan kadar kemurnian biodiesel yang dihasilkan sebesar 98,13\% dan biodiesel yang dihasilkan telah memenuhi standar Standar Nasional Indonesia (SNI) 047182-2006.
\end{abstract}

Kata kunci: Jatropa curcas, transesterifikasi, Microwave, biodiesel.

\section{PENDAHULUAN}

Biodiesel adalah salah satu bahan bakar alternatif yang mempunyai beberapa keunggulan diantaranya mudah digunakan, ramah lingkungan (biodegradable), tidak beracun, bebas dari logam berat seperti Sulfur dan senyawa aromatik serta mempunyai titik nyala yang lebih tinggi daripada petroleum diesel sehingga lebih aman jika disimpan dan digunakan. Biodiesel yang berasal dari minyak nabati dikenal sebagai VOME (Vegetable Oil Metil Ester) dan merupakan sumber daya yang dapat diperbaharui karena umumnya dapat diekstrak dari berbagai hasil produk pertanian dan perkebunan [1].

Salah satu metode yang dapat digunakan pada proses pembuatan biodiesel adalah Microwave, karena Microwave dapat mempercepat proses reaksi dengan menggunakan katalis alkali. Radiasi Microwave dapat meningkatkan kecepatan 
transesterifikasi. Energi Microwave dihantarkan secara langsung pada molekulmolekul yang bereaksi melalui reaksi kimia. Sehingga, perpindahan panas lebih efektif daripada pemanasan secara konvensional dimana panas dipindahkan dari lingkungan [2].

Beberapa penelitian yang telah dilakukan dalam pemanfaatan energi alternatif terbaharukan ini, diantaranya adalah pemanfaatan biodiesel dari minyak nabati. Minyak nabati yang dapat digunakan dalam pembuatan biodiesel contohnya, minyak sawit, minyak jarak pagar, minyak biji karet, minyak kelapa, minyak kedelai, minyak jagung, minyak biji bunga matahari, dan bahkan minyak goreng bekas (minyak jelantah) [3].

Pada penelitian ini, minyak nabati yang yang digunakan adalah minyak biji jarak pagar dengan variabel rasio molar (mol) 1:9, daya 100, 180, 300, dan 450 Watt, konsentrasi katalis (\% b/b) 0,25, dan 0,5, waktu 5, 10, dan 15 menit. Keuntungan dari penggunaan Microwave ini yaitu, Yield dan kualitas produk yang lebih tinggi dibandingkan cara konvensional, konsumsi energi untuk pengoperasian 23 kali lebih rendah, prosesnya lebih ramah lingkungan, waktu reaksinya lebih cepat, perbandingan molar reaktan yang diperlukan lebih sedikit, produk samping yang dihasilkan lebih sedikit.

\section{TINJAUAN PUSTAKA}

\section{Jarak Pagar (Jatropha Curcas)}

Tanaman jarak pagar termasuk famili Euphobiaceae satu famili dengan karet dan ubi kayu. Jatropha Curcas (tanaman jarak pagar) merupakan salah satu tanaman yang paling prospektif untuk diproses menjadi biodiesel karena selain relatif mudah ditanam, toleransinya tinggi terhadap berbagai jenis tanah dan iklim, produksi minyak tinggi, serta minyak yang dihasilkan tidak dapat dikonsumsi oleh manusia sehingga tidak mengalami persaingan dengan minyak untuk pangan. Minyak jarak pagar berwujud cairan bening berwarna kuning dan tidak menjadi keruh sekalipun disimpan dalam jangka waktu lama [4].

Tanaman Jatropha Curcas termasuk tanaman semak dari keluarga Euphorbiaceae yang tumbuh cepat dengan ketinggian mencapai 3-5 meter. Umumnya, seluruh bagian dari tanaman ini mengandung racun sehingga hampir tidak memiliki hama. Tanaman ini mulai berbuah pada umur 5 bulan, dan mencapai produktivitas penuh pada umur 5 tahun. Buahnya berbentuk elips dengan panjang sekitar 1 inchi (sekitar 2,5 cm) dan mengandung 2-3 biji. Usia Jatropha Curcas apabila dirawat dengan baik, dapat mencapai 50 tahun [4].

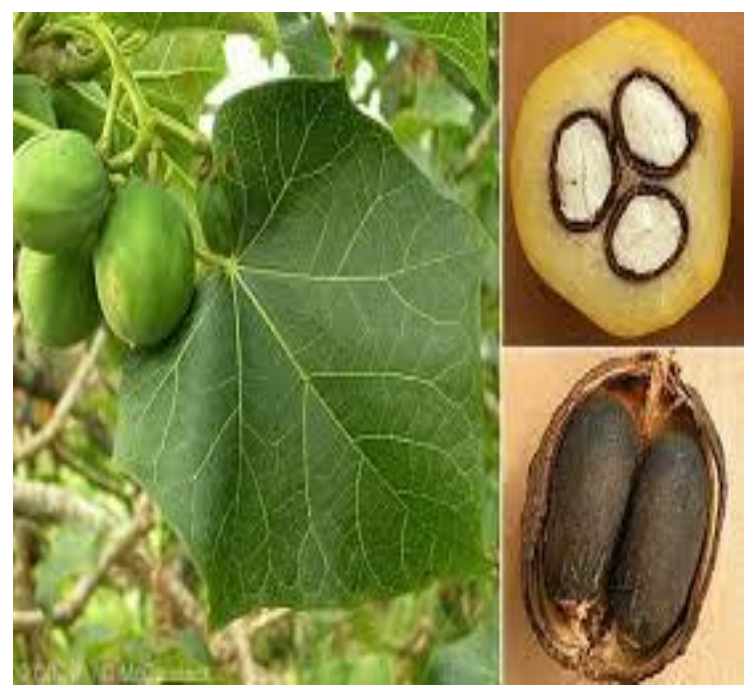

Gambar 1. Tanaman jarak pagar

\section{Komposisi minyak jarak pagar}

Biji jarak diperoleh dari pohon jarak yang menghasilkan biji. Biji jarak pagar terdiri dari $60 \%$ berat kernel (daging biji) dan $40 \%$ berat kulit. Beberapa penelitian menyebutkan dalam satu daging biji terkandung sekitar 45-60 \%. Minyak sehingga dapat diekstraksi secara mekanis maupun ekstraksi pelarut dan sisanya berupa ampas yang bisa digunakan sebagai pupuk kaya nitrogen. Karena kandungan minyaknya yang tinggi, daging biji jarak pagar mudah diekstraksi.

\section{Sifat Fisika dan Kimia Minyak Jarak}

Minyak jarak pagar merupakan jenis minyak yang memiliki komposisi trigliserida yang mirip dengan kacang. 
Tabel 1. Sifat Fisik Minyak Jarak [5].

\begin{tabular}{|l|l|l|}
\hline Sifat Fisik & Satuan & Nilai \\
\hline Titik nyala (flash point) & ${ }^{0} \mathrm{C}$ & 236 \\
\hline Berat jenis pada $20{ }^{0} \mathrm{C}$ & $\mathrm{g} / \mathrm{cm}^{3}$ & 0,9177 \\
\hline Viskositas pada $30^{0} \mathrm{C}$ & $\mathrm{mm}^{2} / \mathrm{s}$ & 49,15 \\
\hline $\begin{array}{l}\text { Residu karbon (carbon } \\
\text { residue on } 10 \% \text { destilasi } \\
\text { residue) }\end{array}$ & $\%(\mathrm{~m} / \mathrm{m})$ & 0,34 \\
\hline $\begin{array}{l}\text { Kadar abu Sulfat (Sulfated } \\
\text { ash content) }\end{array}$ & $\%(\mathrm{~m} / \mathrm{m})$ & 0,007 \\
\hline Titik tuang (pour point) & ${ }^{0} \mathrm{C}$ & $-2,5$ \\
\hline $\begin{array}{l}\text { Kandungan air (water } \\
\text { content) }\end{array}$ & $\mathrm{ppm}$ & 935 \\
\hline $\begin{array}{l}\text { Kandungan Sulfat (Sulfur } \\
\text { content) }\end{array}$ & $\mathrm{ppm}$ & $<1$ \\
\hline Bilangan asam (acid value) & $\begin{array}{l}\mathrm{Mg} \\
\mathrm{KOH} / \mathrm{g}\end{array}$ & 4,75 \\
\hline $\begin{array}{l}\text { Bilangan iod (iodine value) } \\
\text { iod } / 100 \mathrm{~g} \\
\mathrm{minyak}\end{array}$ & 96,5 \\
\hline
\end{tabular}

Tahapan Proses Pembuatan Biodisel

a) Esterifikasi

Esterifikasi adalah proses untuk mengubah asam lemak bebas hasil dari proses degumming menjadi ester dengan hasil samping air. Katalis yang umumnya digunakan pada proses ini adalah katalis yang bersifat asam salah satunya adalah $\mathrm{H}_{2} \mathrm{SO}_{4}$. Reaksi esterifikasi dilakukan pada suhu $60-70^{\circ} \mathrm{C}$ karena pada suhu di atas tersebut metanol akan menguap. Proses esterifikasi diawali dengan mencampur alkohol dengan katalis. Campuran tersebut diaduk selama 10 menit. Setelah itu, campuran katalis dan alkohol ditambahkan ke dalam minyak dan diaduk kembali selama 10 menit. Bila sudah tercampur maka, larutan tersebut dapat dipanaskan pada reaktor. Minyak hasil esterifikasi selanjutnya diendapkan selama 24 jam untuk memisahkan ester dengan hasil sampingnya [6].

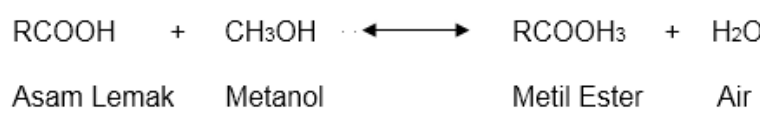

Esterifikasi biasa dilakukan untuk membuat biodiesel dari minyak berkadar asam lemak bebas tinggi (berangka asam > $5 \mathrm{mg}-\mathrm{KOH} / \mathrm{g}$ ). Pada tahap ini, asam lemak bebas akan dikonversi menjadi metil ester. Tahap esterifikasi biasa diikuti dengan tahap transesterifikasi, kandungan air dan katalis asam dihilangkan terlebih dahulu.

b) Transesterifikasi

Reaksi transesterifikasi secara umum merupakan reaksi alkohol dengan trigliserida menghasilkan metil ester dan gliserol dengan bantuan katalis basa. Alkohol yang umumnya digunakan adalah metanol dan etanol. Reaksi ini cenderung lebih cepat membentuk metil ester dari pada reaksi esterifikasi yang menggunakan katalis asam. Namun, bahan baku yang akan digunakan pada reaksi transesterifikasi harus memiliki asam lemak bebas yang kecil $(<2 \%)$ untuk menghindari pembentukan sabun. Reaksi transesterifikasi trigliserida menjadi metil ester adalah:

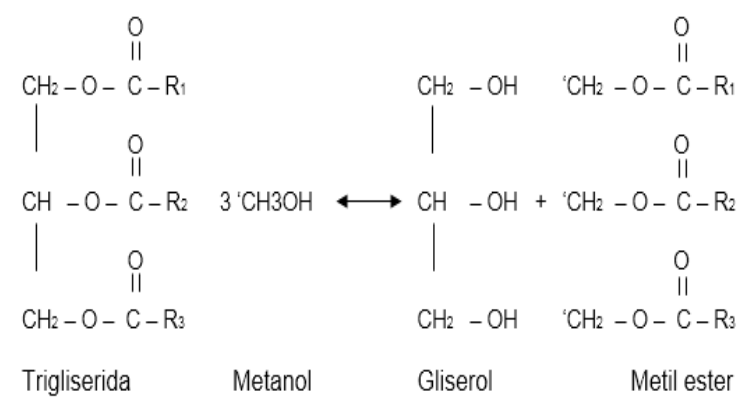

Katalis

Katalis adalah zat yang berfungsi untuk mempercepat laju reaksi dan dapat menurunkan kondisi operasi. Reaksi estererifikasi dan transesterifikasi adalah reaksi yang lambat. Oleh karena itu dibutuhkan katalis guna mempercepat laju reaksi.

a. Katalis Asam

Katalis asam dipilih untuk memproduksi biodiesel dengan kadar asam lemak bebas (FFA) tinggi melalui reaksi esterifikasi. Katalis asam seperti $\mathrm{H}_{2} \mathrm{SO}_{4}$, $\mathrm{HPO}_{4}$, dan $\mathrm{HCl}$ merupakan katalis yang efektif untuk reaksi esterifikasi [7].

b. Katalis Basa

Katalis yang biasa digunakan dalam reaksi transesterifikasi adalah katalis asam dan katalis basa. Katalis yang bersifat basa lebih unggul karena menghasilkan metil ester yang tinggi konversinya dan lebih cepat reaksinya [4]. Katalis basa yang umum digunakan adalah $\mathrm{NaOH}$ dan $\mathrm{KOH}$. Natrium hidroksida $(\mathrm{NaOH})$, juga dikenal sebagai 
soda kaustik, soda api, atau sodium hidroksida, adalah sejenis basa logam kaustik. Natrium Hidroksida terbentuk dari oksida basa natrium oksida dilarutkan dalam air. Natrium hidroksida membentuk larutan alkali yang kuat ketika dilarutkan ke dalam air. Natrium hidroksida biasa digunakan sebagai basa dalam proses produksi bubur kayu dan kertas, tekstil, air minum, sabun dan deterjen [8].

\section{Microwave}

Cara kerja Microwave melalui panas yang terkandung pada gelombang bukan melalui kemampuan pemecahan ikatan kompleks dari FFA atau trigliserida yang terkandung dalam minyak nabati. Pada metode konvensional, panas ditransfer ke reaktan dengan cara konduksi, konveksi dan radiasi. Akan tetapi pada teknologi Microwave, panas ditransfer secara langsung pada reaktan tanpa melalui preheating. Radiasi Microwave akan mengaktifkan berbagai molekul polar dan ionion seperti alkohol sehingga mampu mengubah magnetiknya. Perubahan medan listrik tersebut mengakibatkan interaksi dipol-dipol molekul dan ion-ion bermuatan. Molekul dan ion tersebut akan berputar sangat cepat sehingga menghasilkan panas yang diakibatkan oleh friksi antar molekul dan ion [4].

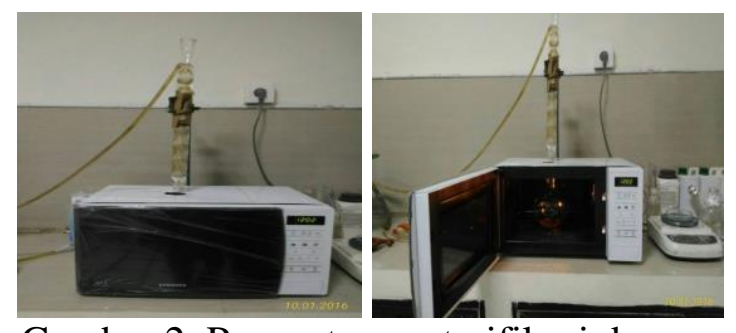

Gambar 2. Proses transesterifikasi dengan Microwave

Parameter untuk perhitungan pada penelitian ini yaitu:

1. Penentuan densitas

Piknometer yang telah bersih dan kering ditimbang dengan teliti. Piknometer diisi dengan minyak biji jarak, kemudian tutup kapiler kemudian ditimbang. Densitas dapat dihitung dengan persamaan 1 .

$$
\rho=\frac{(G-G o)}{V}
$$

Dengan:

$\rho=$ Densitas $(\mathrm{g} / \mathrm{ml})$

$\mathrm{G}=$ berat piknometer berisi minyak (gram)

$\mathrm{G}_{\mathrm{o}}=$ berat piknometer kosong (gram)

$\mathrm{V}=$ volume piknometer $(\mathrm{ml})$

\section{Penentuan Viskositas}

Pengukuran viskositas minyak biji jarak dengan menggunakan viskometer bath pada suhu $40^{\circ} \mathrm{C}$. Pertama, viskositas bath dinyalakan terlebih dahulu kemudian minyak biji jarak dituang kedalam pipa kapiler dengan corong kaca. Minyak biji jarak didiamkan selama 30 menit agar suhu minyak di dalam pipa kapiler tepat $40^{\circ} \mathrm{C}$. Ketingginan minyak dalam kpilet disesuaikan dengan menggunakan pompa hisap, yaitu dibawah garis batas pada lower bulb. Minyak dibiarkan mengalir melewati lower bulb dan upper bulb. Waktu yang diukur adalah waktu untuk melewati lower bulb (a) dan lower bulb (b). Nilai viskositas kemudian dihitung dengan persamaan 2 .

$$
\mu=C \times t
$$

Dengan:

$$
\begin{aligned}
\mu= & \text { viskometer kinematik }\left(\mathrm{mm}^{2} / \mathrm{s}\right) \\
\mathrm{C}= & \text { konstanta kalibrasi viskometer } \\
& \left(\mathrm{mm}^{2} / \mathrm{s}\right) \\
\mathrm{t}= & \text { waktu mengalir }(\mathrm{s})
\end{aligned}
$$

3. Penentuan Bilangan Asam

Penentuan Bilangan Asam dapat dihitung dengan persamaan 3 .

$$
\text { Bilangan asam }=\frac{(A \times N \times 39,997)}{G}
$$

Dengan:

$$
\begin{aligned}
\mathrm{A} & =\text { volume } \mathrm{NaOH} \text { yang dibutuhkan } \\
& \text { untuk titrasi }(\mathrm{ml}) \\
\mathrm{N} & =\text { normalitas larutan } \mathrm{NaOH} \\
\mathrm{G} & =\text { berat sampel }(\text { gram }) \\
39,997 & =\text { bobot molekul } \mathrm{NaOH}(\mathrm{g} / \mathrm{mol})
\end{aligned}
$$

\section{Perhitungan Yield biodiesel}

Perhitungan Yield biodiesel menggunakan persamaan 4 .

$$
\text { yield }=\frac{(\text { gram biodiesel })}{(\text { gram bahan baku })} \times 100 \%
$$




\section{METODE PENELITIAN}

\section{Bahan dan Alat}

Bahan utama dalam penelitian ini berupa minyak biji jarak pagar (Jatrogha curcas) diperoleh dari Surabaya, katalis berupa asam sulfat $\left(\mathrm{H}_{2} \mathrm{SO}_{4}\right)$ untuk proses esterifikasi dan natrium hidroksida $(\mathrm{NaOH})$ untuk proses transesterifikasi. Metanol sebagai pelarut, Aquades untuk pencucian hasil esterifikasi dan transesterifikasi.

Alat utama yang digunakan pada penelitian ini adalah labu leher tiga sebagai reaktor pada proses esterifikasi yang ditunjukkan pada Gambar 3. Alat pembantu berupa pemanas listrik, wadah, thermometer, kondensor, statif, klem, dan ring.

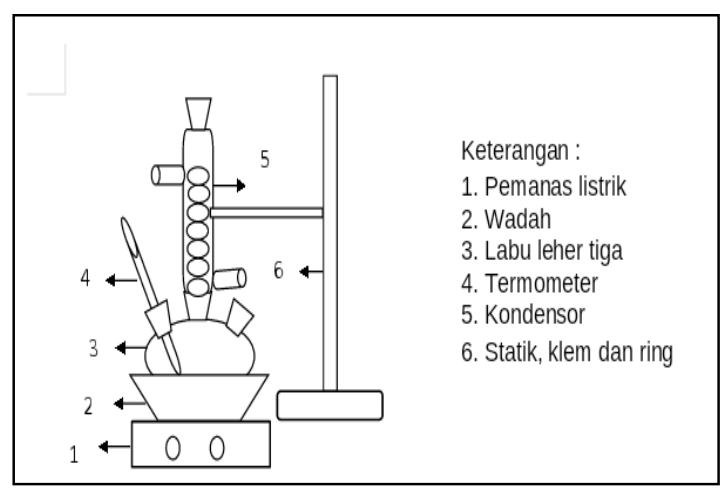

Gambar 3. Rangkaian peratan proses esterifikasi

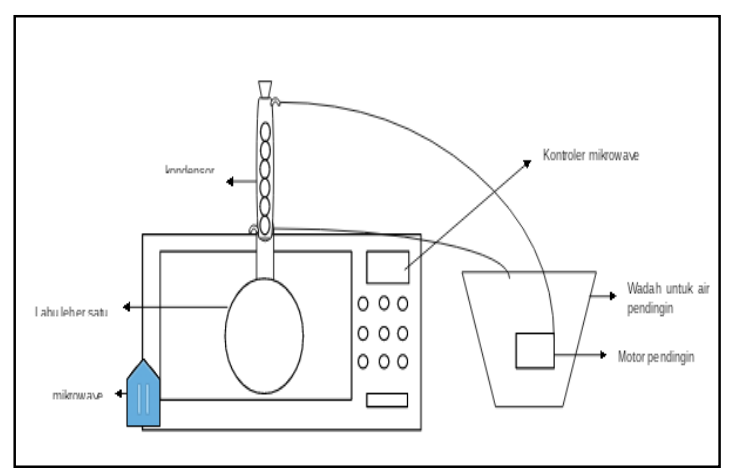

Gambar 4. Rangkaian peratan proses transesterifikasi

Alat-alat pendukung yang digunakan dalam penelitian, piknometer, viscometer oswald, neraca analitik, pipet ukur, spatula, ball filler, beaker glass, corong pisah, pipet tetes, erlemeyer, gelas ukur, cawan porselen, statif, dan botol sampel.
Variabel Penelitian

Variabel tetap: Rasio mol Minyak - Metanol (1:9)

Variabel bebas:

1. Daya (Watt): 100, 180, 300, dan 450

2. Konsentrasi katalis (\% b/b) : 0,25, 0,5, dan 0,75

3. Waktu (menit): 5, 10, dan 15

Variabel terikat:

1. Pengaruh daya gelombang mikro terhadap konversi minyak biji jarak menjadi metil ester.

2. Pengaruh konsentrasi katalis terhadap Yield biodiesel yang dihasilkan.

3. Pengaruh waktu reaksi pada proses transesterifikasi minyak biji jarak pada pembuatan biodiesel dengan menggunakan radiasi gelombang mikro.

\section{Prosedur Penelitian}

Proses pembuatan biodiesel melalui dua tahap, yaitu tahap esterifikasi dan tahap transesterifikasi.

1. Tahap Esterifikasi

Tahap ini memiliki tujuan untuk mengkonversi FFA yang terkandung dalam minyak biji jarak pagar menjadi metil ester dan air. Kadar FFA ini harus diturunkan hingga $<2 \%$ agar dapat dilanjutkan ke tahap transesterifikasi. Tahap ini dimulai dengan mencampur minyak dengan metanol (rasio mol minyak-metanol 1:3) dan katalis $\mathrm{H}_{2} \mathrm{SO}_{4}$ sebanyak 3\% (v/v) di dalam reaktor labu leher tiga. Kemudian melakukan pemanasan selama 60 menit disertai pengadukan. Setelah melalui proses pemanasan, dilakukan pemisahan antara metanol, minyak dan katalis menggunakan corong pemisah selama kurang lebih 24 jam, lapisan bawah berupa metanol yang dapat dimurnikan lagi dan lapisan atas adalah campuran minyak dan metil ester yang selanjutnya dilakukan pencucian dengan aquades. Langkah terakhir adalah proses pemanasan dalam oven bersuhu $110^{\circ} \mathrm{C}$ dengan tujuan untuk mengurangi kadar air dalam minyak. 


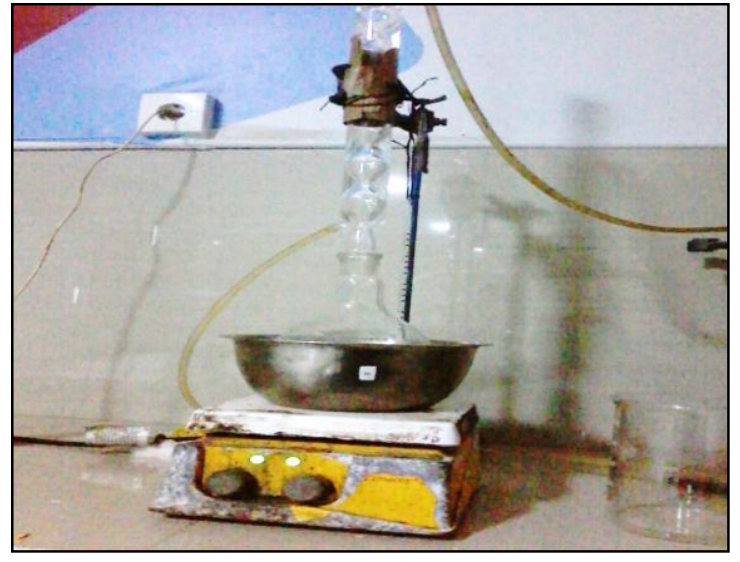

Gambar 5. Proses Esterifikasi

\section{Tahap Transesterifikasi}

Tahap ini merupakan tahap utama dalam penelitian ini, dimana trigliserida yang merupakan komponen utama minyak dikonversi menjadi biodiesel dan gliserol. Prosedur kerja sintesis biodiesel minyak biji jarak melalui reaksi transesterifikasi menggunakan Microwave dengan katalis $\mathrm{NaOH}$. Mula-mula katalis $\mathrm{NaOH}$ (konsentrasi 0,25, 0,5, dan 0,75\%), dilarutkan dalam metanol. Selanjutnya menyiapakan campuran metanol dengan minyak dengan rasio perbandingan 1:9 di dalam reaktor. Didalam reaktor dilakukan mixing antara campuran minyak, metanol, dan katalis. Di dalam Microwave, campuran dalam reaktor akan mengalami pemanasan pada suhu $60^{\circ} \mathrm{C}$ selama 5,10 , dan 15 menit. Hasil reaksi akan dipisahkan secara gravitasional menggunakan corong pisah selama 1 jam, kemudian dipisahkan antara gliserol dan metil ester. Biodiesel hasil transesterifikasi kemudian dicuci menggunakan aquades yang telah dipanaskan hingga suhu $40^{\circ} \mathrm{C}$. Proses pencucian dilakukan sebanyak 3 kali untuk menghilangkan metanol, katalis yang tidak bereaksi dan sabun yang tertinggal dalam biodiesel setelah reaksi. Biodiesel yang telah dicuci masih memiliki sisa-sisa air. Sehingga harus dihilangkan kadar airnya agar biodiesel yang dihasilkan sesuai dengan SNI. Penghilangan kadar air tersebut dengan cara pemanasan menggunakan oven pada suhu $110^{\circ} \mathrm{C}$.

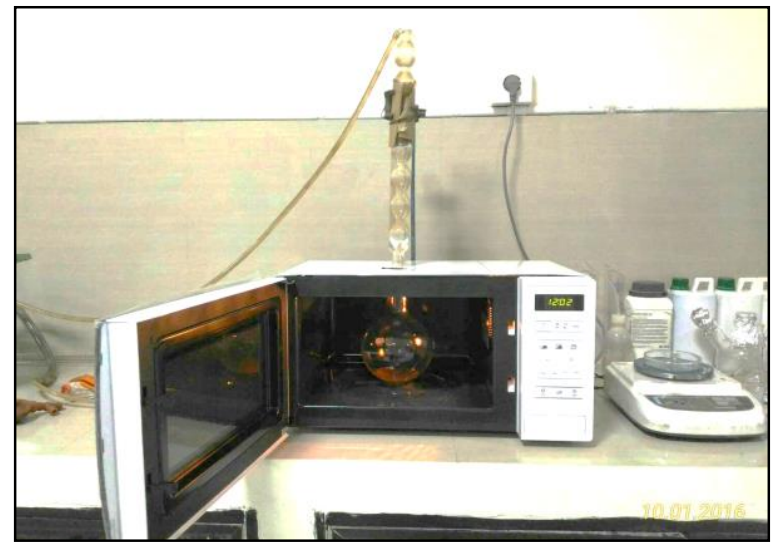

Gambar 6. Proses Transesterifikasi Menggunakan Microwave

Setelah melakukan kedua tahap tersebut, selanjutnya melakukan analisa karakteristik biodiesel dengan melakukan uji kuantitatif yang dilakukan pada hasil produk (biodiesel) adalah uji densitas, uji viskositas, dan angka asam. Dilakukan uji tersebut guna mengetahui kualitas biodiesel yang dihasilkan dengan standar menurut SNI.

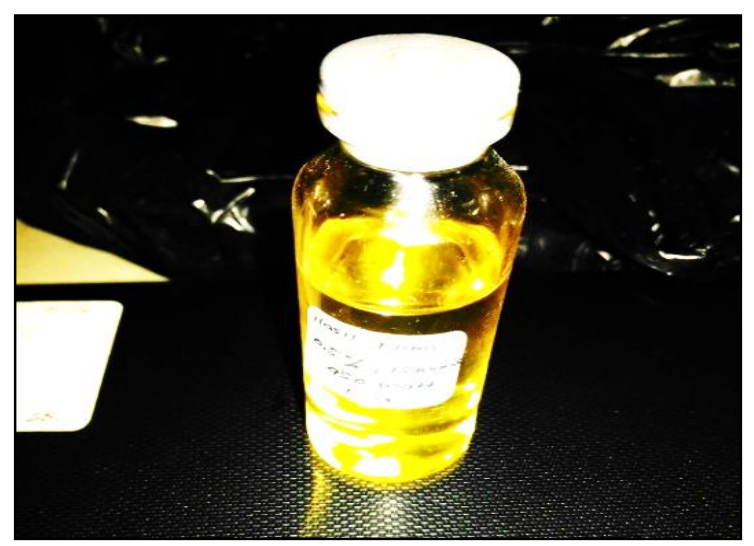

Gambar 7. Produk biodiesel 


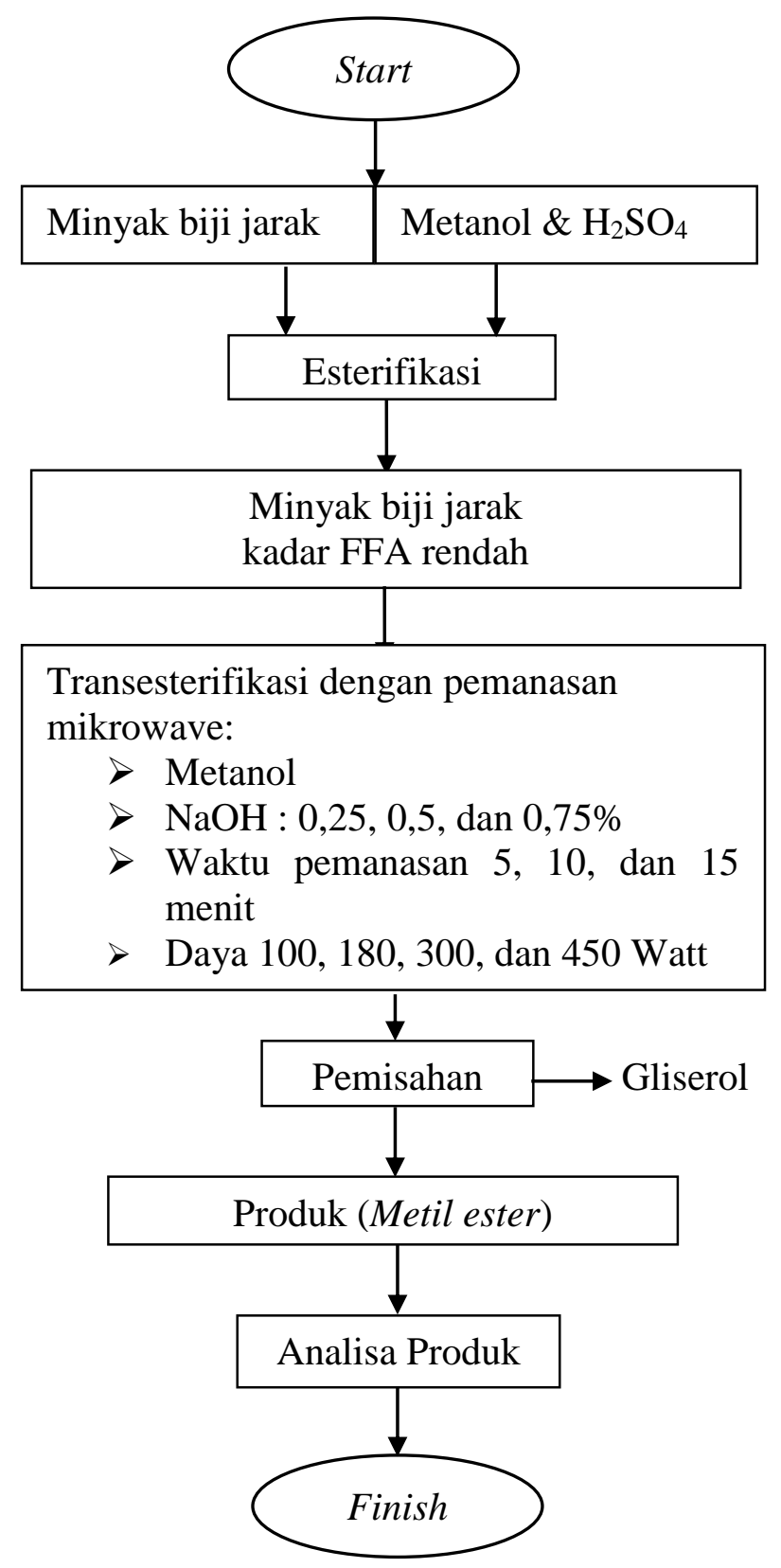

Gambar 8. Diagram Alir Proses Penelitian

\section{HASIL DAN PEMBAHASAN}

\section{Tanaman Jatropha}

Curcas

merupakan salah satu tanaman yang paling prospektif untuk diproses menjadi biodiesel karena selain relatif mudah ditanam, sangat toleran terhadap jenis tanah dan iklim, serta minyak yang dihasilkan tidak dapat dikonsumsi oleh manusia sehingga tidak mengalami persaingan dengan minyak untuk pangan. Minyak jarak pagar berwujud cairan bening berwarna kuning dan tidak menjadi keruh sekalipun disimpan dalam waktu yang lama [4].
Sebelum melakukan penelitian, dilakukan beberapa analisa awal minyak jarak pagar untuk mengetahui data fisis minyak jarak. Didapatkan data awal minyak jarak densitas sebesar $0,919 \mathrm{~g} / \mathrm{ml}$, viskositas $19,84 \mathrm{~mm} / \mathrm{s}^{2}$ dan asam lemak bebas sekitar $4,9 \%$.

\section{Esterifikasi}

Minyak jarak pada umumnya mengandung asam lemak bebas yang sangat tinggi sehingga perlu ada proses esterifikasi untuk mengurangi kadar asam lemak bebas. Proses reaksi esterifikasi minyak biji jarak dilakukan dengan menambahkan katalis asam sulfat $\left(\mathrm{H}_{2} \mathrm{SO}_{4}\right)$, dan pereaksi metanol. Minyak hasil esterifikasi diukur bilangan asamnya, dari hasil perhitungan diperoleh sekitar $2 \%$ hal ini menunjukkan asam lemak bebas yang pada awalnya sekitas 4,9 $\%$ terkonversi menjadi ester, sehingga kandungan asam lemak bebas di dalamnya menjadi lebih rendah dari keadaan semula.

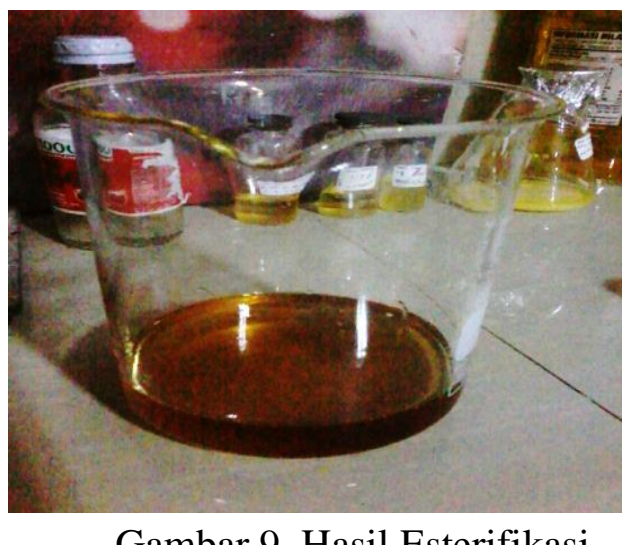

\section{Transesterifikasi}

Pembuatan biodiesel dengan gelombang mikro yang telah dilakukan menggunakan tiga macam variabel. Variabel tersebut yaitu daya Microwave, konsentrasi katalis $\mathrm{NaOH}$, dan waktu reaksi. Daya Microwave dilakukan antara lain 100, 180, 300, dan 450 Watt yang dikeluarkan oleh gelombang mikro dari Microwave. Konsentrasi katalis $\mathrm{NaOH}$ divariasikan 0,$25 ; 0,5 ;$ dan $0,75 \%$. Sedangkan untuk waktu reaksi selama 5, 10, dan 15 menit. Pembuatan biodiesel dilakukan dengan semua variabel yang ada untuk mengetahui pengaruh dari ketiga macam variabel untuk 
memperoleh produk biodiesel yang paling baik.

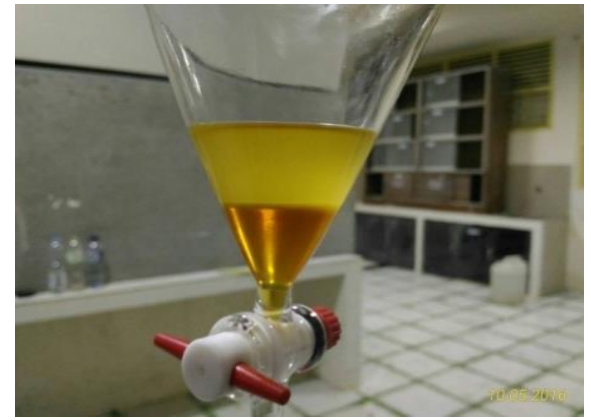

Gambar 10. Hasil Transesterifikasi

\section{Pengaruh daya mikro terhadap viskositas produk}

Minyak biji jarak mempunyai viskositas kinematik yang tinggi, sehingga dilakukan proses dua tahap yaitu esterifikasi dan transesterifkasi. Dengan melakukan proses esterifikasi dan transesterifikasi minyak biji jarak menjadi biodiesel terjadi penurunan viskositas kinematik yang sangat signifikan. Viskositas kinematik minyak biji jarak yang mulai dari $19,84 \mathrm{~mm}^{2} / \mathrm{s}$ sedangkan setelah melalui proses esterifikasi didapatkan $11,35 \mathrm{~mm}^{2} / \mathrm{s}$, kemudian hasil transesterifikasi berkisar 2-6 $\mathrm{mm}^{2} / \mathrm{s}$. Ini berarti penurunan viskositas hampir 1/9 kali viskositas minyak biji jarak murni.

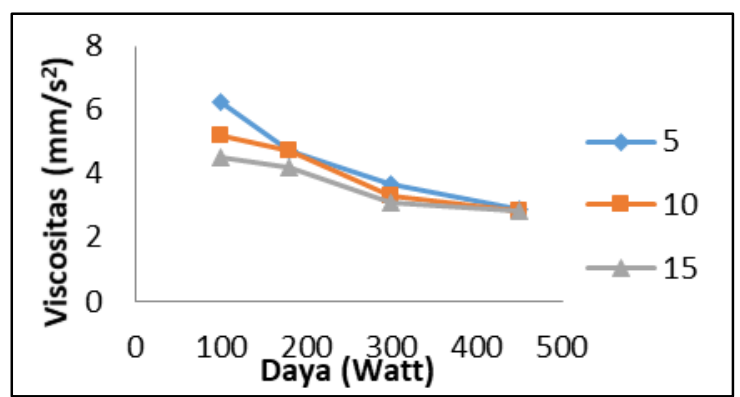

Gambar 11. Pengaruh daya Microwave terhadap viskositas produk pada jumlah katalis $0,25 \%$.

Gambar 11 menunjukkan pengaruh daya Microwave saat proses transesterifikasi terhadap viskositas hasil biodiesel pada jumlah katalis 0,25\% massa minyak biji jarak. Grafik tersebut menunjukkan terjadi penurunan viskositas dari daya 100 Watt hingga 450 Watt. Penurunan viskositas menandakan bahwa produk yang dihasikan semakin baik. Perununan viskositas ini disebabakan karena semakin besar daya akan memberikan efek thermal yang besar pula yang ditandai dengan peningkatan suhu yang sangat cepat.

\section{Pengaruh Daya Microwave Terhadap Yield Produk Biodiesel}

Yield merupakan perbandingan antara massa biodiesel yang dihasilkan (produk) dengan massa minyak biji jarak. Range Yield pada penelitian ini dengan menggunakan daya 100 Watt dengan katalis $0,25 \%$ dan waktu yang bervariasi, Yield berkisar antara $0,28-0,42$, hal ini menunjukkan daya 100 Watt bahwa belum mampu menghasilkan biodiesel yang maksimal. Tetapi pada daya 400 Watt dengan variasi waktu dan jumlah katalis saat proses transesterifikasi menghasilkan Yield lebih tinggi pula berkisar antara 0,43-69,09.

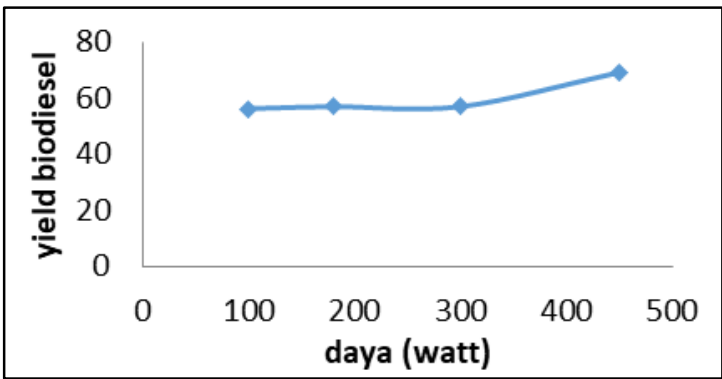

Gambar 12. Pengaruh Daya Terhadap

Yield Produk yang dihasilkan pada berbagai waktu reaksi dan konsetrasi katalis

Gambar 12 Merupakan daya terhadap Yield produk dengan berbagai konsentrasi katalis. Pada daya 100 Watt didapatkan Yield biodiesel yang lebih rendah dibandingkan daya yang lain. Sedangkan dengan adanya peningkatan daya optimum memberikan efek thermal yang besar ditandai dengan adanya kenaikan Yield pada berbagai konsentrasi katalis dan waktu rekasi. 


\section{Pengaruh waktu reaksi terhadap viskositas produk}

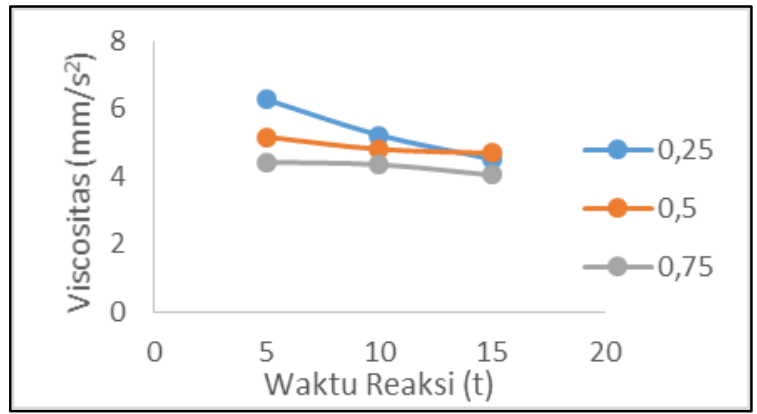

Gambar 13. Pengaruh waktu reaksi dan viskositas produk pada daya 100 Watt.

Dari gambar 13 terlihat bahwa nilai viskositas terendah terjadi pada waktu pemancaran selama 15 menit. Hal ini disebabkan karena pada waktu pemancaran 5 menit campuran anatara minyak biji jarak, katalis dan metanol belum bereaksi sempurna sehingga mengakibatkan viskositas biodiesel masih tinggi. Viskositas merupakan sifat yang sangat penting dalam penggunaan bahan bakar minyak. Jika minyak terlalau kental, maka akan menyulitkan dalam pemompaan dan sulit untuk dialirkan. Berdasrkan SNI 04-71822006 untuk mutu biodiesel, nilai viskositas kinematik adalah $2,3-8 \mathrm{~mm}^{2} / \mathrm{s}$ [9]. Bila dilihat pada nilai viskositas kinematik terendah yang didapat pada hasil penelitian adalah 2,7 untuk daya 450 Watt.

\section{Pengaruh Waktu Reaksi Terhadap Yield biodiesel}

Pengaruh waktu reaksi terhadap Yield biodiesel pada daya 100 Watt seperti ditunjukkan Gambar 14.

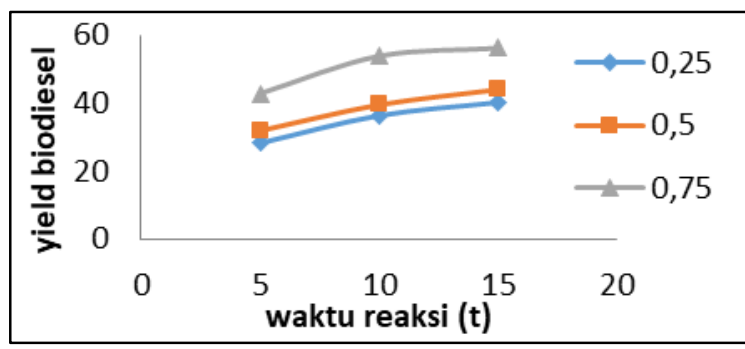

Gambar 14. Pengaruh waktu reaksi terhadap Yield biodiesel pada daya 100 Watt

Pada gambar 14 dapat dilihat bahwa waktu reaksi sangat berpengaruh terhadap
Yield biodiesel yang diperoleh, dimana pada grafik di atas untuk daya 100 Watt, waktu reaksi 15 menit dengan konsentrasi $0,75 \%$ menghasilkan Yield biodiesel sekitar 0,40 0,56 . Sedangkan untuk daya 450 Watt dengan waktu 15 menit dan konsentrasi $0,75 \%$ Yield biodiesel menurun kemungkinan pada daya 450 dan waktu reaksi 10 menit Yield sekitar 0,69 merupakan titik optimum perolehan biodiesel, sehingga pada waktu 15 menit menurun menjadi 0,65 .

\section{Pengaruh konsentrasi Katalis Terhadap Viskositas Produk}

Viskositas kinematik menjadi tolak ukur kualitas hasil biodiesel, karena untuk mendapatkan biodiesel dengan kualitas baik biodiesel harus memenuhi standar SNI yang telah ditentukan.

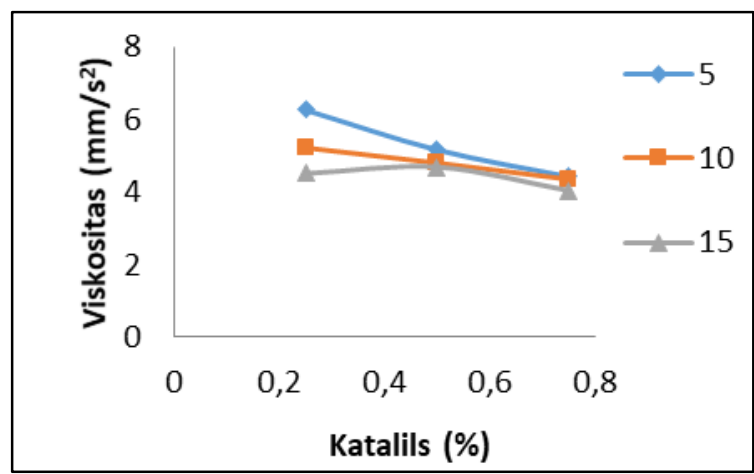

Gambar 15. Pengaruh konsentrasi katalis terhadap viskositas produk biodiesel dengan dengan daya 100 Watt.

Berdasarkan data penelitian pada gambar 15 diketahui bahwa biodiesel yang memenuhi standar adalah hasil biodiesel dangan jumlah katalis $0,5 \%$ dan $0,75 \%$ $\mathrm{NaOH}$ pada ke empat daya tersebut sesuai pembacaan Microwave. Dikatakan memenuhi standar karena sampel tersebut mempunyai viskositas antara $2-6 \mathrm{~mm}^{2} / \mathrm{s}$, ini artinya sampel biodiesel memenuhi standar SNI. Jika semakin kecil konsentrasi biodiesel yang digunakan maka jumlah metil ester yang terbentuk juga jumlahnya sedikit. Hal ini membuktikan bahwa, semakin besar jumlah katalis maka kemungkinan pembentukan metil ester juga semakin besar, dilihat dari kecenderungan viskositasnya yang semakin tinggi. 
Pengaruh Konsentrasi Katalis terhadap Yield biodiesel yang dihasilkan

Berdasarkan penelitian yang telah dilakukan, berikut ini adalah grafik pengaruh konsentrasi katalis terhadap Yield yang dihasilkan pada berbagai waktu.

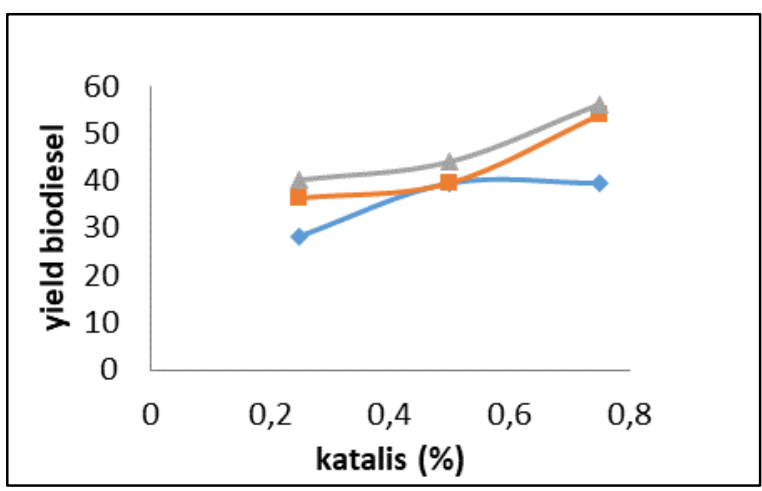

Gambar 16. Pengaruh konsentrasi katalis yang digunakan terhadap Yield produk yang dihasilkan pada setiap waktu reaksi

Dari Gambar 16 terlihat perbedaan Yield produk yang dihasilkan pada konsentrasi katalis 0,$25 ; 0,5$; dan $0,75 \%$ pada daya 100,180 , dan 300 Watt terletak pada range 0,28 - 0,57. Sedangkan Yield produk pada daya 450 Watt terletak pada range 0,43-0,69. Dari grafik di atas, terlihat bahwa konsentrasi $0,75 \%$ cenderung lebih baik, jika dibandingkan dengan katalis 0,25 $\%$ dan 0,5 \% katalis. Yield produk yang dihasilkan jika menggunakan konsentrasi katalis $0,75 \%$ pada beberapa daya lebih baik daripada konsentrasi katalis $0,25 \%$ dan 0,5 $\%$.

\section{KESIMPULAN}

Dari hasil penelitian dan pembahasan maka dapat disimpulkan sebagai berikut:

1. Pemanfaatan gelombang mikro pada reaksi transesterifikasi minyak jarak dapat dilakukan dengan konsentrasi yang lebih rendah serta waktu reaksi yang lebih cepat jika dibandingkan dengan metode konvensional.

2. Yield biodiesel yang dihasilkan pada masing variasi daya 100, 180, dan 300 watt, waktu reaksi 15 menit dengan konsentrasi katalis $0,75 \%$ Yield sebesar $56,12 \%, 56,84 \%$, dan 56,86\%.
Sedangkan pada daya 450 watt diperoleh Yield 69,09\% dengan waktu reaksi 10 menit, dan konsetrasi katalis 0,75\% dengan kadar kemurnian biodiesel yang dihasilkan sebesar 98,13\% dan biodiesel yang dihasilkan telah memenuhi standar SNI 04-7182-2006.

\section{REFERENSI}

[1]. Kusumaningsih, T., Pranoto, Saryoso, R. 2006, "Pembuatan bahan bakar diesel dari minyak jarak". Jurnal Bioteknologi 3 (1), hal 20-26. Jurusan Kimia FMIPA Universitas Sebelas Maret Surakarta.

[2]. Lertsathapornsuk V., P. Ruangying, R.Pairintra dan K. Krisnangkura, 2004. Continuous transethylation of vegetable oils by Microwave irradiation. Thailand.

[3]. Faisal A., Usman T., Alimuddin A. H. 2015, "Transesterifikasi Langsung Mikroalga (Chlorella, Sp.) Dengan Radiasi Gelombang Mikro". Volume 4(2), halaman 76-80. Pontianak, Universitas Tanjungpura.

[4]. Dewi D. C. 2015, "Produksi Biodiesel Dari Minyak Jarak (Ricinus Communis) Dengan Microwave". Fakultas Teknik, Universtas Negeri Semarang.

[5]. Hambali, E. 2007, "Teknologi Bioenergi”, Argo Media, Jakarta.

[6]. Arsandi Y. A., Hamidi N., Wahyudi S., 2011, "Pengaruh Variasi Waktu Pemancaran Gelombang Mikro Proses Esterifikasi Pembuatan Biodiesel Minyak Biji Karet (Hevea brasiliensis)", 
Fakultas Teknik Universitas Brawijaya, malang.

[7]. Budiman, A., R.D.

Kusumaningtyas, Y. S. Pradana, dan N. A. Lestari. 2014., "Biodiesel Bahan Baku, Proses dan Teknologi". Gadjah Mada University Press. Yogyakarta.

[8]. Kasim R. 2012, "Esterifikasi Asam Lemak Bebas pada campuran asam oleat dan minyak sawit murni menggunakan Microwave". Teknologi hasil pertanian, universitas negeri gorontalo.

[9]. Balai Rekayasa Disain dan Sistem Teknologi (BRDST) Badan Pengkajian Dan Penerapan Teknologi. 2011. 